Journal of Environmental Science and Sustainable Development

Volume 3

Issue 2 December

Article 6

$12-31-2020$

\title{
TINY HOUSE: REFLECTION ON PARTICIPATORY ACTION \\ RESEARCH AS A TOOL OF INQUIRY IN THE KAMPUNG COMMUNITY
}

\author{
Elita Nuraeny \\ Universitas Indonesia, elitanuraeny@ui.ac.id \\ Amira Paramitha \\ Universitas Indonesia, amiraparamitha@ui.ac.id \\ Herlily Herlily \\ Universitas Indonesia, herlily@gmail.com
}

Follow this and additional works at: https://scholarhub.ui.ac.id/jessd

Part of the Other Architecture Commons, and the Urban, Community and Regional Planning Commons

\section{Recommended Citation}

Nuraeny, Elita; Paramitha, Amira; and Herlily, Herlily (2020). TINY HOUSE: REFLECTION ON

PARTICIPATORY ACTION RESEARCH AS A TOOL OF INQUIRY IN THE KAMPUNG COMMUNITY. Journal of Environmental Science and Sustainable Development, 3(2), 302-328.

Available at: https://doi.org/10.7454/jessd.v3i2.1045

This Original Research Article is brought to you for free and open access by the School of Environmental Science at UI Scholars Hub. It has been accepted for inclusion in Journal of Environmental Science and Sustainable Development by an authorized editor of UI Scholars Hub. 


\title{
TINY HOUSE: REFLECTION ON PARTICIPATORY ACTION RESEARCH AS A TOOL OF INQUIRY IN THE KAMPUNG COMMUNITY
}

\author{
Elita Nuraeny $^{1 *}$, Amira Paramitha ${ }^{1}$, Herlily ${ }^{1}$ \\ ${ }^{1}$ Department of Architecture, Faculty of Engineering, Universitas Indonesia, Depok, 16424, \\ Indonesia \\ *Corresponding author: elitanuraeny@ui.ac.id
}

(Received: 30 November 2020; Accepted: 29 December 2020; Published: 31 December 2020)

\begin{abstract}
At the end of 2015, the government of Jakarta declared a river normalization program to widen both banks of the Ciliwung River and increase its channel capacity. Approximately 15 meters of inspection road was to be constructed immediately. To avoid eviction, 223 households in Kampung Anak Kali (KAKC) reduced their domestic spaces by shearing five meters off their houses, forcing them to allocate less space for daily activities, including cooking, bathing, and washing. Living in a tight space, constructing a tiny house is a necessity, not a lifestyle choice. The residents of KAKC, therefore, live in limited areas for survival, and each develops a house with unique characteristics to suit their needs. In response, a community engagement program was conducted in 2019 to redevelop houses and solve the domestic space issue in KAKC. Through four case studies, the project implemented Participatory Action Research (PAR) to share knowledge in spatial occupation between homeowners and professional architects. The result of the community engagement project is various spatial adaptations in small spaces with architectural consideration in safe, health, and financial affordability. This paper investigates deeper into how the project performed PAR as a tool of inquiry and criticizes the result. In the end, this paper concluded that PAR, which is established as a method in community-based projects, can be applied in a smaller subsystem such as a household.
\end{abstract}

Keywords: Community; Participatory Action Research (PAR); Riverbank settlement; Tiny house; Kampung.

\section{Introduction}

The problem in the current housing problem is due to a one-sided solution from the policymakers, as addressed by Hamdi (2010). The housing issue becomes more controlled by the government, the more it becomes politicized and less suitable to answer people's need for proper housing. Instead of solving the housing shortage, the governments created more demand, which further increased the price and alienated their intended users (Hamdi, 2010). Hamdi, however, offered two paradigms. The first one is the provider paradigm, which supplies and provides the production of houses. The 
second one is the antithesis, where it controls the production. According to Hamdi, the second paradigm is more encouraged this day because it speaks of partnership and empowerment between public and private (Hamdi, 2010).

Housing issues are also a prominent problem in Jakarta, as 15,804 people were forced to share a square kilometer (Badan Pusat Statistik Provinsi DKI Jakarta, 2019). The situation had caused less fortunate citizens to squeeze together in a small area, inhabiting leftover and unguarded spaces with irregular shapes in the city, which later became known as kampungs. Originally, in kampungs, houses were built autonomously on a vast land and made of whatever material was available, without strict rules or guidelines (Colombijn, 2010). Therefore, according to Harjoko (2009), the people, community, and physical attributes of the kampung continued to grow, following their need to settle down, rest, eat, work, and communicate (Harjoko, 2009). However, as the city grew and expanded, kampungs were squeezed into the center of Jakarta, restricting the space for kampung inhabitants. The residents were now crowded in tight spaces.

From the perspective of colonial administrators, the kampung was problematic as the government's power was insufficient to penetrate the area (Cobban, 1993). These perspectives continued to evolve with various government efforts to fix the kampung. An early example of government attempts to improve kampung began in the early 1920s with the "Kampung Question" (kampongkwestie), which the idea is adapted to the "Kampung Improvement Program" in the 1960s, and "the 1000 Towers" in the early 2000s. These programs were conducted on the premise that the kampungs were unsanitary and hazardous (Colombijn, 2010; Cobban, 1993). Even the former Vice President, Jusuf Kalla expected "the 1000 Towers" project to "bring the urban poor out of their slum-like environments" (Kusno, 2012). Previous KIPs focus on kampung physical attributes to fit modern culture and space in the city (Harjoko, 2009). However, as a contrasting custom against the government's law, kampungs have often been victimized by the wider system and slowly displaced from their space to make way for development.

The current housing model's problem is due to a one-sided solution from the policymakers, as addressed by Nabeel Hamdi (2010). The more the government has controlled the housing issue, the more politicized the issue has become and less suitable as an answer to the people's need for proper housing. Instead of solving the housing shortage, the government created more demand, which further increased housing prices and alienated their intended users (Hamdi, 2010). Hamdi, however, offered two paradigms. The first was the provider paradigm, in which the government supplies and provides the production of houses. The second is its antithesis, where the government controls the 
production. According to Hamdi, the second paradigm is currently more encouraged as it focuses on partnership and empowerment between public and private entities (Hamdi, 2010).

The smallest dwelling space produced in the kampung is a house, which bears a unique sense of individuality in every part of it. Heidegger (2001) explained that to dwell is the epitome of human existence and experience on earth through buildings. As an effort to spare and preserve, the need to dwell became a representation of the human relationship with one's surrounding environment, with others, and with the divinities. According to Sashi Caan (2011), the cave was the earliest habitable environment found by our ancestors. It gave humans a sense of security and safety, as well as a chance to evolve and design. Caan then elaborates on how the design process continued as humans, inspired by the cave, ventured outside, and created other structures (Caan, 2011). Thus, to design is to preserve lives in a particular area by utilizing materials offered by the surrounding environment. However, remaining in one place was no longer the sole factor that propelled people to dwell. In the modern world, where more people live in cities, humans no longer arrange their world around themselves but remodel it into "networks of rivers and beams" (Sloterdijk, 2016), meaning that the decision to dwell in the urban context relates to the availability and accessibility of people and places. In the same way, houses in kampungs are the manifestation of the human desire to remain in spaces that provide them safety, security, and-most importantly-proximity to other places and human beings.

The relationship between people, the environment, and their society is observable through their everyday spaces, especially in interior and spatial arrangements. Spatial programming requires structuring "things, persons, and practices that constitute the social world" (Dovey \& Dickson, 2002). It indicates how design must be inclusive for all where spaces can expand and adapt following the owner's needs. Till and Schneider (2005) described the ability to adjust to the inhabitants' needs as soft uses. Compared to soft use, plans in hard use are more definite and predetermined by the architect, although users might control some aspects (Till \& Schneider, 2005).

The need for shelter as an idea beyond physical materiality is further elaborated by Coolen and Meesters (2012), who describe dwelling as a subsystem of the environment and cultural artifacts. Other than individual manifestation, to dwell is also a social and community interaction where the homemaking process is equally meaningful and valuable (Coolen \& Meesters, 2012). This type of self-preservation and social conduct is like the idea of self-build, which is currently developing in Europe, especially as an answer to the housing issue, such as affordability and availability. As eloquently reflected by Michaela Benson and Iqbal Hamiduddin (2017), self-build is, most importantly, a complete social process beyond expressing the identity, pride, and achievement of 
creating something. The need to dwell exceeds the physical appearance and transcends into social conduct on a larger scale. Iqbal Hamiduddin (2017) argued that self-builders often become "builders of the neighborhood" due to their space-making exercise in domestic spaces, also contributing to the neighborhood commons. A clear example of this situation can be seen in most kampungs in Jakarta where domestic activities-washing dishes and entertaining guests-are often conducted on the street. The activity, therefore, acts as a new communal pocket to socialize with others communally. Hamiduddin (2017) described the phenomenon as a cyclical one termed as "community shaping space, space shaping community."

Preserving oneself, amassing goods, and interacting with others as a community is basic needs to shelter. These were further integrated with other requirements to produce wages as a means of survival, the needs of action, to be social and politically active, and to maintain power over one another in a neighborhood (Harjoko, 2009). Referring to the statement by Henri Lefebvre (1991), "the social relations of production have a social existence to the extent that they have a spatial existence; they project themselves into a space, becoming inscribed there, and in the process producing that space itself", there is striking relevancy to how people in kampungs produced places of their own. Places were created to be the end products of social and political practices, making kampungs spaces defined by their social reproduction, daily household activities, social interactions, and engagements with political and economic structures (Martin, 2003). Although everyone produces their own space, they continue to interact with each other, which creates a complex entity that continues to evolve through the interaction of individual collective or communal planning (Nurgandarum et al., 2019). Therefore, to understand how spaces in kampungs are created, it is crucial to have a comprehensive knowledge of how these actors produce their spaces, individually and collectively.

In urban environments, tiny houses offer solutions to housing problems: it can provide temporary housing, transitional accommodation, or even a mobile studio for frequent travelers (Ford \& Gomez-Lanier, 2017). Tiny houses can also be used as permanent living spaces. Without specific minimum space requirements, homeowners of tiny houses have limitless opportunities to create their own spaces. The tiny house is also deemed eco-friendly as it reduces energy consumption and waste (Kilman, 2016). Larger houses have caused massive environmental damage as they require immense resources for construction, operation, and maintenance (Shearer \& Burton, 2018). Tiny houses, on the other hand, leave smaller carbon footprints compared to different housing types.

However, most tiny house movements studied in current publications reflect the Western settlements, especially in North America (Ford \& Gomez-Lanier, 2017; Kilman, 2016; Shearer \& 
Burton, 2018). Moreover, living in a tiny house is seen as an alternative lifestyle for sustainable and affordable housing in the future (Ford \& Gomez-Lanier, 2017; Shearer \& Burton, 2018). In Jakarta's kampungs, the practice of living in small spaces is not a choice or lifestyle but a required action to maintain roofs above heads. With the average salary in DKI Jakarta less than IDR4,500,000 a month (around US\$ 319) (Badan Pusat Statistik Provinsi DKI Jakarta, 2019), building construction and maintenance is a struggle for most households who can barely provide their daily needs. Sharing a kilometer with other 15,804 people in DKI Jakarta is another issue where land availability is scarce and too expensive. Living in tiny space, therefore, is not a choice: it is part of kampungs' survival and everyday lives.

Based on how kampungs emerged in the city and spatial production of domestic space, Kampung Anak Kali Ciliwung (Kampung at Ciliwung River Tributary, shortened to KAKC) is an example of how living in limited spaces. However, they were disturbed in 2015 by the government of Jakarta who declared a river normalization program to displace the residents from the land they called home since the 1960s. To defend their dwelling rights, KAKC tried to negotiate with the government. Both parties agreed on a term that allowed residents of KAKC to retain their homes but required them to cleave five meters off their houses to create an inspection road and rotate their façades toward the Ciliwung River (Hairani, 2017). Unfortunately, since the demolition was conducted haphazardly, it left a serious construction hazard. Concrete and steel jutted out, doors and windows opened to floorless rooms, or ceramic and glass debris, and many threatening conditions. The situation was dangerous for the well-being of its residents, and immediate action was required. Figure 1 depicts the result of the 2015-cutting in KAKC.

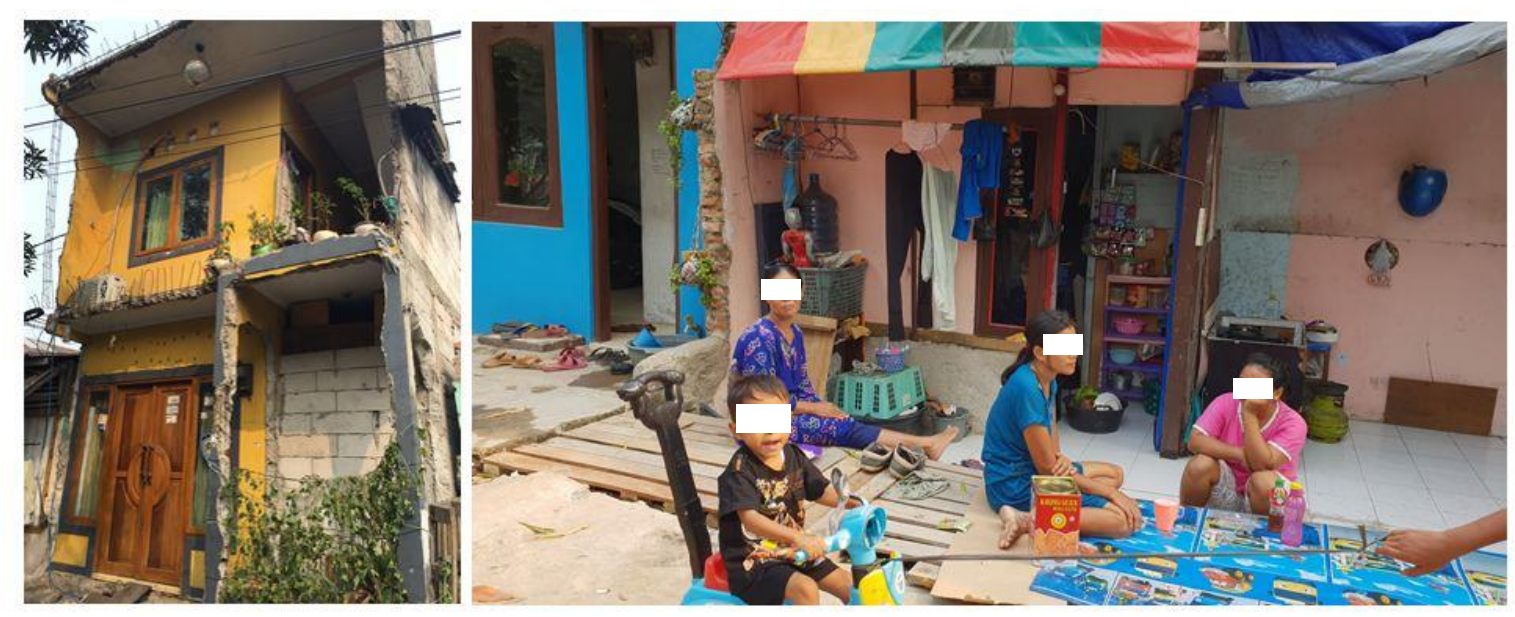

Figure. 1 Houses condition in KAKC after cutting 5-meters off their houses. 
In 2016, the KAKC community collaborated with research academics and nongovernmental organizations (NGOs) to design a master plan known as Kampung Inspeksi + Wisata Kampung (Inspection + Kampung Tourism) as a response to the community will improve their living conditions after cutting their houses the year before. The plan includes issues of sanitation and waste treatment projects completed in 2019. In their effort to repair their damaged houses, the residents of KAKC made a savings group as funding for renovation. Once a house is fully renovated, the homeowner will return the money to the savings group to subsidize the next renovation. In accelerating the renovation, a collaborative project between Universitas Indonesia and Arsitektur Swadaya Fasilitas, funded by the Asian Coalition of Housing Rights, constructed a house for four households. The project was finished in 2016 and became a precedent for future renovation for other residents in KAKC.

In 2019, following the existing funding framework and the community's will to renovate, we continued the initiative by conducting a housing redevelopment program. The main idea of this project is to accommodate and diversify options for various spatial occupations for other renovations in KAKC. The discussion in this paper will further investigate the implementation of Participatory Action Research (PAR) as a response to settlement conditions in KAKC after the houses were split in 2015. We argued that the application of the method is especially important in a neighborhood context, especially in kampung, where house designs are the outcome of spatial practices in response to people's daily needs. As mentioned before, people in Jakarta's kampungs, including $\mathrm{KAKC}$, are accustomed to living in a minimalist living condition with limited space and materials. According to Colombijn (2010), houses in kampungs are self-built, showing the ingenuity and craftsmanship of kampung's inhabitants. However, due to the sudden cutting in 2015, the small living space they once had was even tighter and adjusting to the new space was a constant battle people still fighting until today.

The project focused on houses that had lost their wet areas (kitchen, bathroom, and washroom) and lost structural quality to the cutting or other events. The entire process of PAR involved the KAKC community, professional architects, and research academics in creating a common understanding of housing, particularly in the KAKC context. The community engagement goal was to propose a new prototype that is safe, healthy, and financially affordable houses for the densely compacted settlement, especially in Jakarta, based on the understanding of each house and how they can best meet the growing environmental demands. The template will have essential areas and space for modification in the future. 
From an academic perspective, this paper offers a new discussion on PAR as a design method that can be used as a tool of inquiry, producing various designs responding to spatial practice in kampungs, especially the inhabitant's pre-existing building knowledge. In understanding PAR as a tool of inquiry in kampungs, this paper extends the discussion into two majoring discourses. First of all is the fact that publications on housing are government-centered (Taylor, 1987; Yudhohusodo \& Salam, 1991) or too focused on architectural and technical issues (Suryo, 2017; Widyahantari, et al., 2013). It fails to understand that the "social space is dynamic space" (Awan et al., 2011) and cannot be fixed to a single mode. It is crucial to recall the nature of architecture as a community and participatory endeavor where space is formed from the involvement of many actors and phenomena, in which this paper aims to fill. The second discussion is how PAR is often implemented on a large scale, as the smallest as a neighborhood-scale (Hamdi, 2010). Using PAR at a domestic level is rare, if not new. From the Indonesian context, implementing PAR as a tool of inquiry in kampung is a novel idea and criticism to the conventional architectural design process carried out by experts.

\section{Methods}

The project relies on the qualitative methodology, known as PAR, a collaborative initiative between community engagement, research, and education to respond to social and environmental issues (Kindon et al., 2007a). The term PAR does not originate from the space-making discipline. Rather it is adapted from an understanding of social sciences. Sharing the sentiment, with its roots in community activism, Action Research's goals emphasize its features of collective action and reflections by participants to create change toward improvement. This research process believes that there is plurality in perspective and interpretations and as a result, knowledge in seeing a single phenomenon to determine action and reflection on it (Kindon et al., 2007b). Using action and reflection as the vehicle, PAR is about learning and knowledge production specific to the context of the phenomenon. (McTaggart, 2006). The emphasis on the word "participatory" demands that each participating actor eliminate hierarchical role specifications. The act of research and knowledge production can be done together with "ordinary people" (Kindon et al., 2007a) to bridge the gap between the conceptual world and the lived world to create an action (Jones et al., 2005). PAR must be understood as a research method that is democratic and noncoercive with and for-rather than onparticipants. (Kindon et al., 2007a).

After Herbert Simon, in his book, The Sciences of the Artificial (1972), the author seeks to restore the social dimension of design as interdisciplinary research involving its users, its design 
process, and the resultant change as a combination of interpretations of the designer and the user on a phenomenon (Simon, 1972; Katoppo, 2015). The action will ensure that the design produces a more contextual solution (Roth, 1999). The discourse on the social dimensions of design sets the tone for the current architectural body of knowledge that places architecture in the context of social science, as opposed to the pure sciences. As a discipline in a cycle between thinking and action, architectural design, in this context, is designing with a participatory nature with the goals of implementation (Katoppo, 2015). This view continues to grow to offer "a new role of architecture as a participatory collective construction process for emancipatory empowerment" (Stickells, 2011; Katoppo 2015). This paper offers a view of the spaces in kampung-in this context, a house-using this new role of architecture.

As one of the building blocks in kampungs, the house should be understood as the spatial production of the everyday practice of homeowners. Before other stakeholders, such as architects and researchers, took their part in kampungs, the community acted as designers of their respective spaces. Houses are the result of an integrated understanding of their needs, availability of materials, and also limited construction skills. The spaces created are already a simple form of "research" by dissecting their own everyday experience and carrying out an "action" in the form of the construction of a house. From this perspective, when other stakeholders such as architects and researchers get involved, the architecture should not be left to the architects alone. The decision to create architecture must be divided equally between all actors-architects and community alike (De Carlo, 2005). As experts with knowledge in building construction, architects bring their value systems, which are often at odds with the users. Participation from both parties is required to address the gap between professionals and users, even in the project's early stages (Jones et al., 2005). The architect should not pursue abstractions; rather, he/she should project themselves into the user's spatial context, physical, and social environments (Till, 2005). Recognizing and respecting each other's knowledge are significant steps of concrete participation. Design failures in major cities are the outcome of biased perspectives in handling an urban-scale problem. Allowing inclusive participation from local collaborators becomes the fundamental factor, creating ownership and willingness to preserve what has been created (Jones et al., 2005).

If we posit architecture in social contexts, it has never been neutral in the sense that it should be able to become vehicle empowerment through democratic design (Katoppo, 2015). All stakeholders will have knowledge that will contribute to the design processes, both technical and conceptual, from professional education or practical knowledge collected from relevant lived experience. This view obliterates the previous notion of certain stakeholders with the monopoly and control of the 
knowledge and for whom the design processes are conducted (Kindon et al., 2007b). Here, all participants are entitled to produce a new perspective of space relevant to the context of the phenomenon. Design processes encourage participants to produce contextual knowledge and continue with the physical production of space that celebrates the human sociospatial connection. It resonates with PAR goals to employ the act of research for knowledge production based on a continuous process of action and reflection by combining participant's perspectives and the interpretations of a single phenomenon. When this is applied in a context where "unconscious design" is already in the process of spatial formation, the use of continuous repetition of planning, action observation, and evaluation becomes essential. In the kampung case, the knowledge that comes from stakeholders will easily assimilate with what shared knowledge accumulates there. As a result of shared knowledge, space will be scrutinized by the same perspective, creating a continuous assembling and disassembling of attributes as the knowledge evolves.

PAR never indicates itself as a method or procedure with step-by-step instructions to follow. It defines itself "as a series of commitments to observe and problematize through practice the principles for conducting a social enquiry" (McTaggart, 2006). To apply PAR, a researcher must adopt a participatory view to being situated, and reflective and accepting of the ongoing process of inquiry as an act of getting to know. Thus, PAR is an 'orientation to inquiry' that can be methodically developed following the existing knowledge in the context (Kindon et al., 2007b).

As seen in Figure 2, this paper offers to use PAR as a tool of inquiry to investigate kampung's spatial knowledge using four houses in KAKC as the case. The current condition of the house stands as the product of the interplay between the homeowners' lived experience and the community commitment to defend their security of tenure before researchers and professional architects contribute their inherent knowledge. Each homeowner will collaborate with professional architects and facilitated by research academics in redeveloping their house after the cutting in 2015 . The community's everyday life knowledge is then discussed with the researcher and architect spatial urban and technical knowledge of a house and a city, thus creating a house because of this combined knowledge. As the smallest part of the village, which is influenced by the kampung's physical and social structure, the community will be involved in making big decisions such as which house to choose for renovation, the design to be built first, and the finance for the development. 


\section{PARTICIPATORY ACTION RESEARCH AS A TOOLS OF INQUIRY}

\begin{tabular}{l} 
STAKEHOLDER \\
\hline RESEARCHER ARCHITECTS \\
\hline $\begin{array}{l}\text { IDENTIFYING COMMUNITY'S GOAL } \\
\text { MAKING PARAMETER }\end{array}$ \\
\hline ACTION \\
MAKING TERM OF REFERENCES \\
FOR ARCHITECT \\
MAKING TERM OF REFERENCES FOR \\
HOMEOWNER'S CANDIDATE \\
\hline
\end{tabular}

\begin{tabular}{l} 
SIAKEHOLDER \\
RESEARCHER COMMUNITY LEADER \\
\hline
\end{tabular}

IDENTIFYING COMMUNITY'S GOAL

MAKING PARAMETER

\begin{tabular}{l} 
ACTION \\
$\begin{array}{l}\text { MAKING TERM OF REFERENCES } \\
\text { FOR ARCHITECT } \\
\text { MAKING TERM OF REFERENCES FOR } \\
\text { HOMEOWNER'S CANDIDATE }\end{array}$ \\
\hline \\
STAKFHOIDER \\
\begin{tabular}{ll|}
\hline RESEARCHER & COMMUNITYLEADER \\
ARCHITECT & COMMUNITY \\
& HOMEOWNER \\
\hline
\end{tabular}
\end{tabular}

ESTABLISHING TRUST
UNDERSTANDING COMMUNITY'S GOAL
DISCUSSING PERSPECTIVE ABOUT HOUSE
DISCUSSING PERSPECTIVE ABOUT EVERYDAY
ACTIVITY

ACTION

PAIRING OF HOUSE AND ARCHITECT MAKING PLANS FOR EACH PARS

STAKEHOLDER

RESEARCHER

ARCHITECT

COMMUNITY LEADER

COMMUNITY

HOMEOWNER

DISCUSSING DESIGN WITH COMMUNITY

ALIGNING RESULT WITH COMMUNITY'S GOAL

ACTION

CHOOSING THE HOUSE TO BE BUILT

\section{STAKEHOLDER}

RESEARCHER COMMUNITYLEADER

IDENTIFYING ISSUE

VERYFING COMMUNITY'S GOAL

TRANSLATING COMMUNITY'S GOAL

TO HOUSE CRITERIA

\section{ACTION \\ CHOOSING 4 COUPLING UNIT \\ CREATING KEY ASPECT FOR THE HOUSE}

STAKEHOLDER

RESEARCHER HOMEOWNER

ARCHITECT

PRE DESIGN

DESIGN WITH COMMUNITY

\section{ACTION}

UNDERSTANDING THE SITE

UNDERSTANDING EVERYDAY LIFE

IDENTIFYING HOUSES CRITERIA

DEVELOPING APPROACH

DESIGN DISCUSSION

\section{SHARED UNDERSTANDING ABOUT HOUSES}

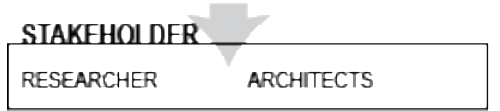

STAKFHOUDRR
COMMUNITY COMMUNITY LEADER

STAKFHOIDFR

HOMEOWNERS

DESIGN PROTOTYPE OF HOUSE FOR FUTURE RENONATION

SHARES UNDERSTANDING ABOUT HOUSE RENOVATED HOUSE

Figure 2. The implementation of PAR as a tool of inquiry for the redevelopment project at KAKC 
The case study will show how each case develops its approach to using PAR through a narrativedescriptive discussion. The result of this collaborative work is a prototype that possessed the quality of context-based, suitable for daily needs, and financially affordable, especially for riverside kampungs in Jakarta. With PAR as the primary method, the redevelopment project collects data from the house (building structures, preliminary information on the house's occupants, and documenting the existing site) and in-depth interviews with the residents. The collected information is used by both collaborators to draft initial ideas and future references for a dwelling prototype. Using PAR as a tool of inquiry demands the ability to be adaptive, innovative, and responsive towards facing a research question or problem in a specific context, developing the generated information towards an action or a material for collaborative reflection. PAR's value does not lay on a successful product, but also in the process of research, the produced information, and in the development of skill, knowledge, or the development of the participant itself during the research experience.

\section{Results and Discussion}

Following the first step, an open forum between the KAKC community and the research team was conducted to decide which households will participate. Each household proposed by the community refers to three factors below:

a. The house is in need of structural renovation and no longer accommodates the daily needs;

b. Consists of two adjacent houses (later known as the coupling unit) that can share the core structure to reduce construction costs; and

c. The residents will receive a loan from the community fund for the construction process and return the budget through a series of interest-free installments. The scheme was designed to help the chosen residents while offering an equal chance for other residents to participate in the future cycle of the project.

Based on those aspects, the forum chose four candidate houses from each kampung to design two coupling units, which will collaborate with an architect to design a healthy and affordable prototype. The final composition can be seen in Figure 3. 


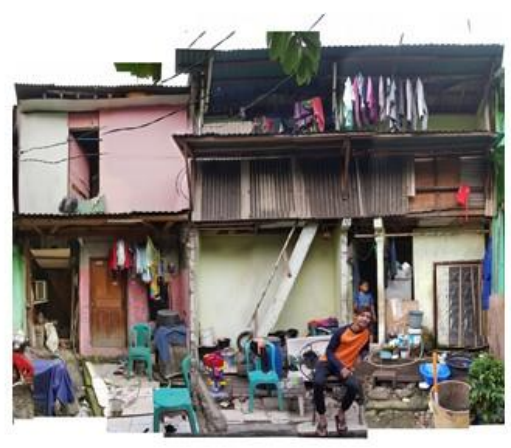

COUPLING UNIT 01 - KAMPUNG LODAN

house 01 owner: $\mathrm{S}$ occupants: 4 people house 02 owner: $A$ occupants: 10 people

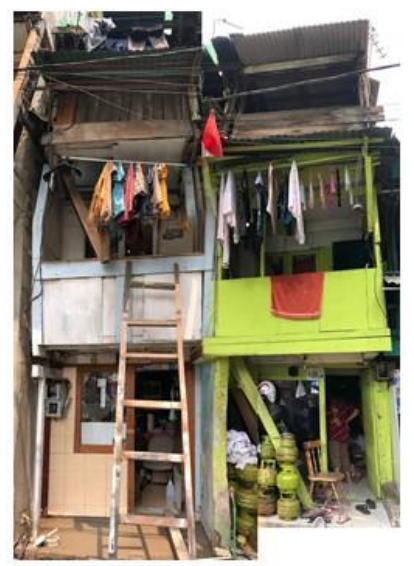

COUPLING UNIT 03 - KAMPUNG KRAPU 1 house 01 owner: W occupants: 6 people house 02 owner: $\mathrm{R}$ occupants: 6 people

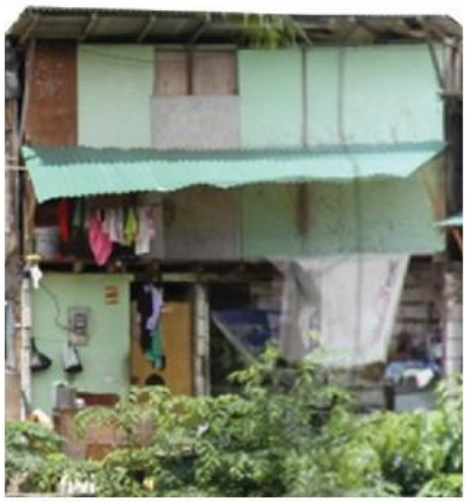

COUPLING UNIT 02- KAMPUNG TONGKOL house 01 \& 02 owner: $R$ occupants: 10 people

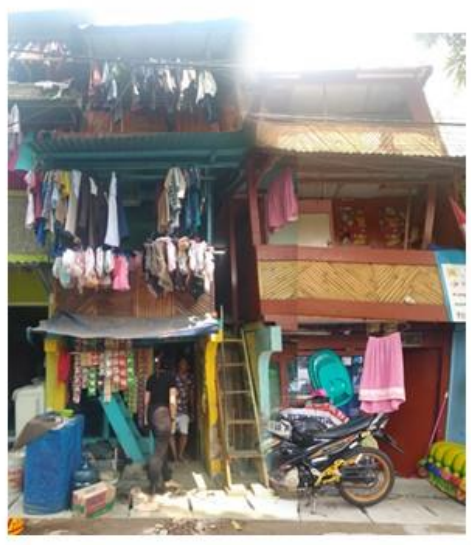

COUPLING UNIT O4 - KAMPUNG KRAPU 2

house 01 owner: J occupants: 22 people house 02 owner: $\mathrm{E}$ occupants: 6 people

Figure 3. Final unit and configuration for the house redevelopment in KAKC

Later, the participating architects received a term of reference (TOR) for the program, consisting of the background of the project, the existing condition, and dimensions of the two houses in each coupling unit, information on the occupants in each coupling unit, and the goal of the project. TOR will be an introduction, not only about the project but also to the current condition of each coupling unit and $\mathrm{KAKC}$ in general.

There are seven key aspects that the architect needs to consider:

1. Design is created based on collaboration with the occupants;

2. Consider sharing the primary utilities and structure communally among the two households; 
3. The budget must not exceed IDR 70 million ( USD 4,500) per coupling unit or IDR 35 million ( USD 2,300) per house;

4. Designing a plan for a core aspect of the house;

5. Creating a plan for possible expansion and development in the future;

6. Utilizing material and building techniques that are environmentally friendly and easy maintenance; and

7. Reconsidering the possibility of reusing old materials already on-site.

\subsection{Pre-design: Understanding the site and everyday lives}

According to Columbijn (2010) and Harjoko (2009), kampungs' growth follows the residents' needs, including their houses. Squeezed in between historical landmarks and harbor, people in KAKC are no strangers in adjusting their spatial occupancy in limited space. Living in small spaces and reusing materials that are seen as an upcoming dwelling trend for a future in other countries (Ford \& Gomez-Lanier, 2017; Kilman, 2016; Shearer \& Burton, 2018), are common practices in KAKC. More importantly, based on the preliminary survey and plans, each kampung in KAKC shows their spatial adaptability based on the context that displays their unique characteristics.

Based on the preliminary survey and current plans, each kampung has its characteristics. The coupling units in Kampung Krapu and Kampung Tongkol extend and leave a narrow space expanding to the back. In Kampung Krapu, the average length is $\sim 3.5$ meters and $\sim 6$ meters wide. Each house's size responds to the remaining space between the irregular shape of the river, the boundary of the next building, and access to enter the house. With a relatively large space between the river and the next building in Kampung Krapu, a narrower space is required, one that expands in the back so that all houses will have access to the street in Kampung Krapu.

The unit in Kampung Tongkol has more width space due to its two entrances leading from the kampung street and military-owned field located on the west side of the house. Unlike houses in Kampung Krapu and Kampung Tongkol, coupling units at Kampung Lodan expand in width with an average measurement of eight meters. The widths of the houses, however, are less than three meters. The coupling house in Kampung Lodan is situated in an approximately 90-degree turn of the river, leaving little available space between the river, street, and the next buildings. To meet the spatial needs in an irregular and narrow plot of land, houses in Kampung Lodan tend to have a wide shape with a smaller width.

Another notable characteristic is the location and availability of wet areas. In Kampung Krapu and Tongkol, the wet area is located at the houses' back and front. Bathrooms are located at the 
back of the houses, while clothes-washing activities are located at the entrance, facing the street. Most of the KAKC residents use the municipal water supply and groundwater for laundry and cooking activities. The water source and space availability are the determining factors for the location of the house's wet areas, where it gravitates to the access point of the municipal water in front of the house. Water can be used immediately and flows out to the sewers in front of the house. In Kampung Krapu, natural wells are located behind some of the houses. This well is a source of water for residents before the municipal water system enters Kampung Anak Ciliwung. We can find wet areas in Kampung Krapu by following the connection point with the municipal water system and the locations of natural wells.

With the wet areas facing the street, the occupants of Kampung Krapu and Tongkol have better air circulation in their wet areas, but their excess water will still swamp the street. Unlike the other two kampungs, wet areas in Kampung Lodan are located inside the back of each house. One of the houses in a coupling unit does not have proper ventilation, as the bathroom and kitchen are almost inseparable, which could be a potential threat to resident health.

The height for each unit is also different between kampungs. Dwellings in Kampung Krapu have at least three stories, one story higher than other kampungs in KAKC. The third floor, however, does not represent the density of each household. For example, in the Coupling Unit 03, each household has six occupants. Another example of an imbalance floor-to-occupant ratio is represented by Coupling Unit 04 , which is occupied by $\mathbf{J}$ and his family of 22 persons, versus the six residents occupying Household E. For J, E, and other inhabitants of Kampung Krapu, a new floor is financially beneficial as a renting space. The difference in spatial use between Kampung Krapu and other kampungs in KAKC is related to its strategic location. Unlike the other kampungs, the entrance of Kampung Krapu is located near the intersection of Krapu Street and Pakin Street. This busy junction connects Sunda Kelapa Harbor and Old Town Jakarta. Not far from the converging streets is Bahari Museum, one of the tourist spots in North Jakarta, as shown in Figure 4. Most clients who rent rooms in Kampung Krapu work as dock laborers at Sunda Kelapa or cyclers at Fatahillah Square. 


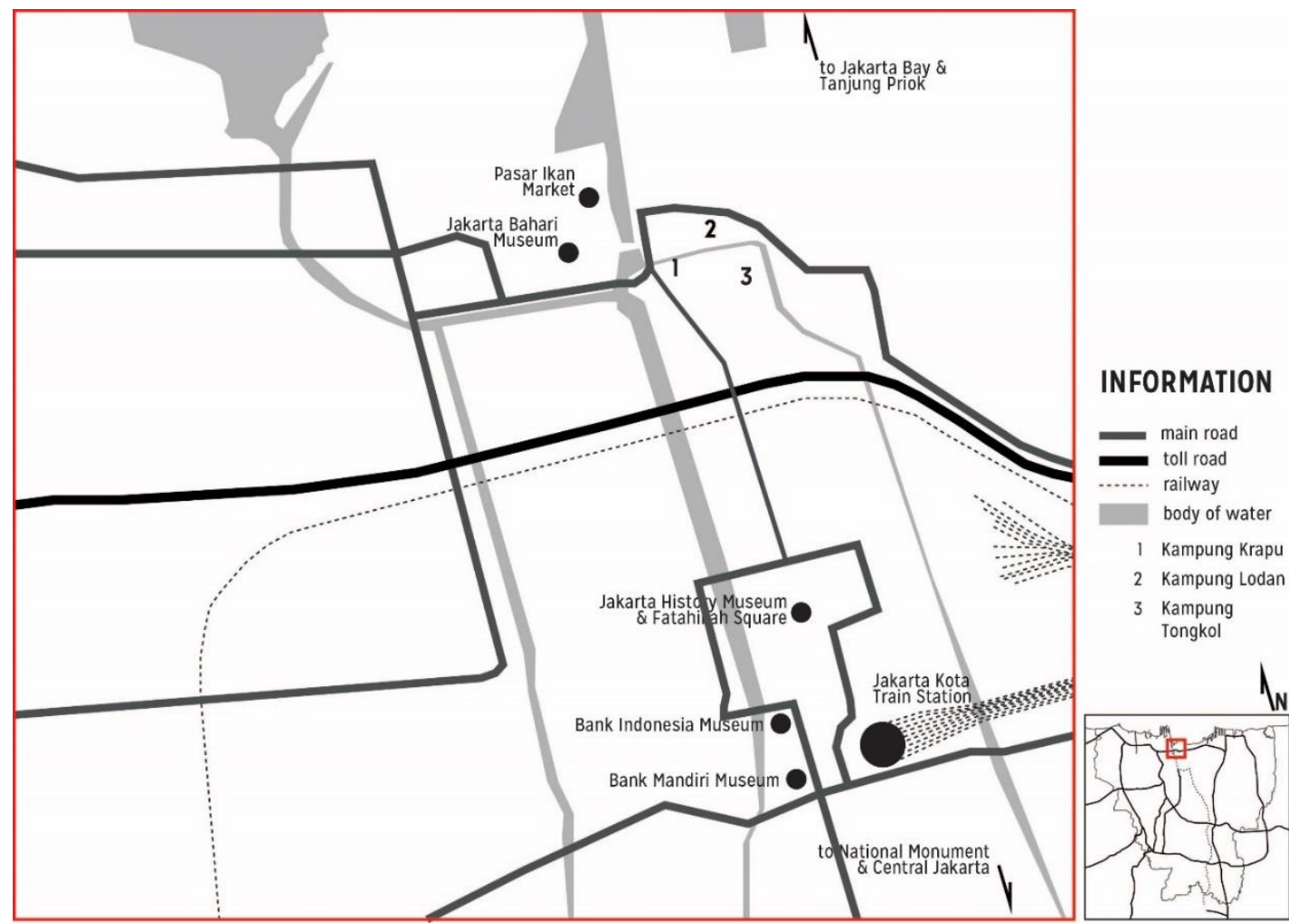

Figure 4. Shows the position and proximity of Kampung Krapu, Tongkol, and Lodan to other places in North Jakarta

In terms of their daily lives in KAKC, the occupants share relatively similar lifestyles. Men are working and rarely seen at home, even on weekends. Three main activities occur at home: relaxing or sleeping, cooking, and bathing. However, units at Kampung Krapu and Tongkol also operate home-based businesses in their houses. As previously discussed, renting parts of their houses became a trend among homeowners in Kampung Krapu. From four households in Kampung Krapu who participated in the project ( $\mathrm{E}$ and $\mathrm{J}$ at Coupling Unit 04; $\mathrm{W}$ and $\mathrm{R}$ at Coupling Unit 03), three families opened their rooms for leasing. Among the participants in Kampung Krapu, only J does not follow the accommodation business model. Instead, J's wife sells home-cooked meals and cold beverages for additional family income.

The homeowners add the 2nd or 3rd floor of the house to provide space for their children as they grow and need their own spaces. In the case of Kampung Krapu, the 2nd floor was inhabited by their children's families who were married or reserved for the children if they wanted to return to live. For those who have smaller core family, the extra space can generate revenue as rented rooms. Therefore, homeowners prefer to customize their homes so that all activities can be done on the 1st floor of the house. The new living arrangement expands opportunities for vertical house expansion for rental income. 
Transparency in communication between experts and nonexperts is crucial in participatory research (Till, 2005). Conjuring a positive environment for discussion between the occupants and architects is an essential design step. Moreover, a personal conversation is important to gain a neutral and leveled understanding of building knowledge from stakeholders. Therefore, with an architect being responsible for one coupling unit, a strong appreciation is expected. It is crucial to provide the architect with information on the residents' needs, not necessarily their wants (Jones et al., 2005). Figure 5 shows how observation and communication become insightful data. This particular figure illustrates the architect's effort to understand S and A's daily activities in Coupling Unit 01 to create a design that resonates with their needs. The four architects collaborating on this engagement project sought to build trust through social visits. Through casual discussion, the architect managed to unravel details on the family's daily lives and needs. It also allows the architect a chance to inspect the structural condition of the house and conduct a preliminary assessment of whether to reinforce or rebuild the structure.

Dialog between the architect and the occupants opens to various details, not just on the residents' daily lives, but also on the social dynamic in each household. Concrete evidence of this relationship can be seen inside R's household in Kampung Tongkol (unit 02). Based on the interview, the Coupling Unit 02 belongs to a single household. However, the occupants insist that the house belongs to two different families: R's family and her uncle. In further discussion, there is a social tension between the two and led to the separation of their entrances, affecting space occupation inside their house. In this house, there is only one kitchen at R's uncle's dwelling area. R and her family are hesitant to use it because the kitchen is in the same room with the uncle's shop and bedroom. Avoiding conflict and maintaining peace between occupants become significant points for this coupling unit. In kampung, where space is scarce, and many occupants live in it, spatial separation becomes a severe issue that needs to be resolved. In R's example, the separation will cost her health due to the lack of proper air ventilation and social conflict. 


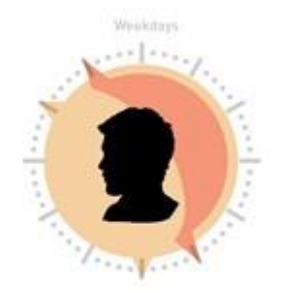

S
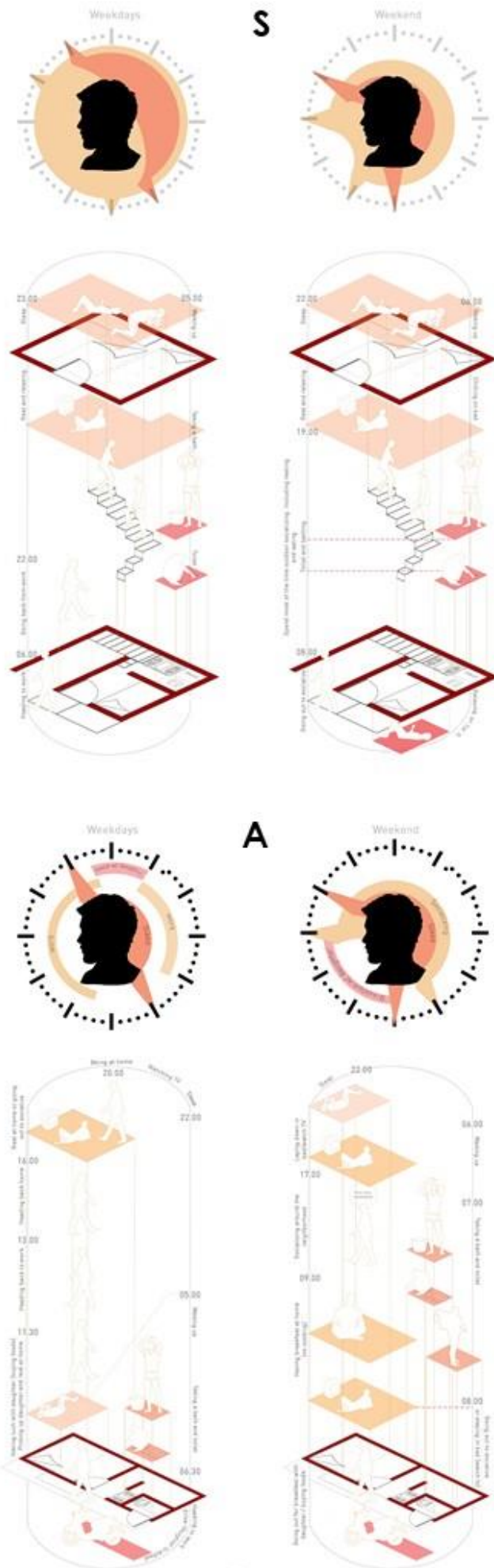

A
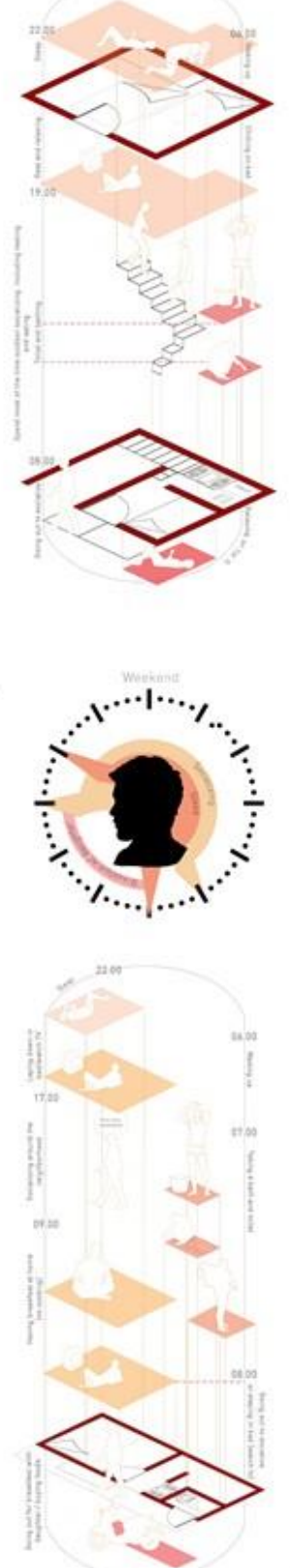

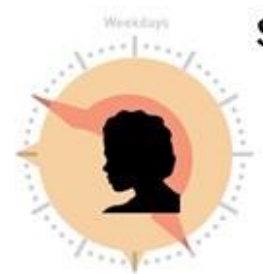

S's wife

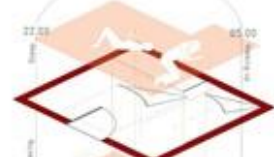

A's daughter
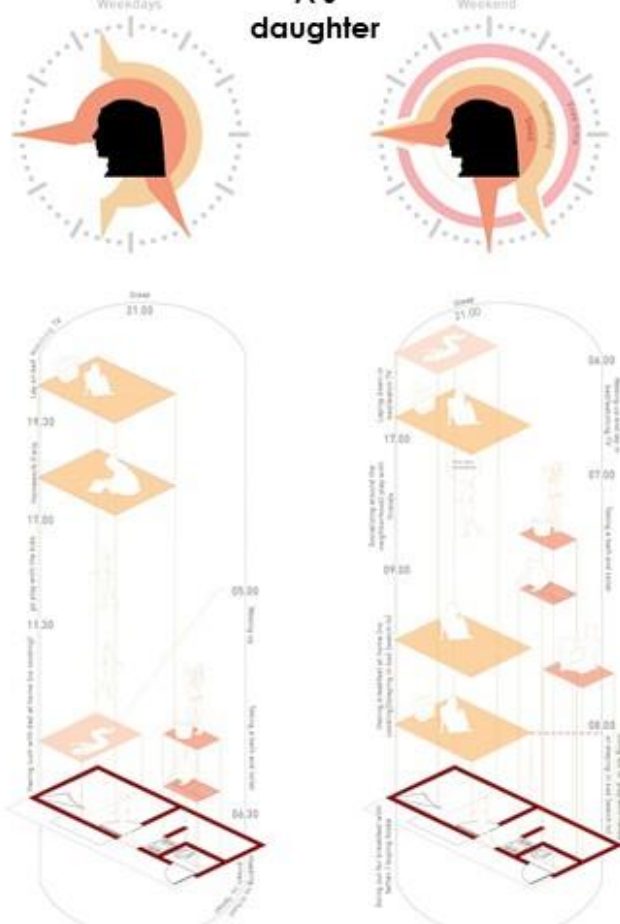
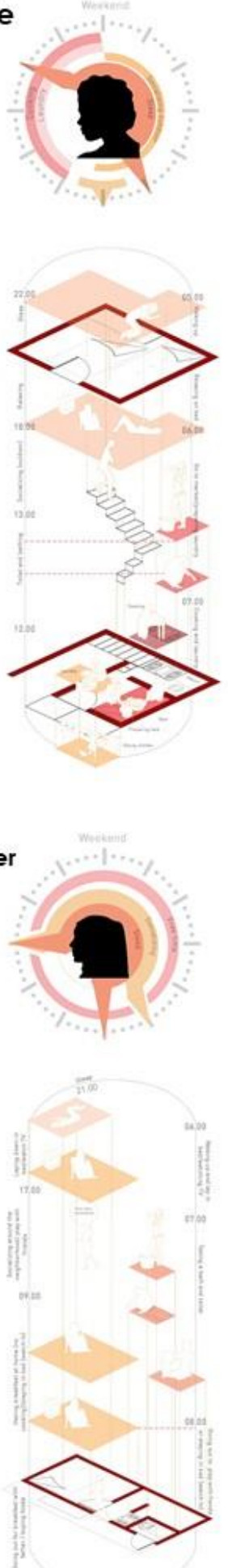

Figure 5. Illustration of daily activities and space occupancy in the Kampung Lodan unit

\subsection{Design with community}

Based on the information they gathered, each architect created a preliminary design for each coupling unit. DI (the architect responsible for the Coupling Unit 01) focused on the lack of space 
for all occupants, both in S's and A's households. According to DI's observation, both houses' daily activities are centered on the floor, from cooking to sleeping. DI came up with the idea to expand the surface for daily activities he called "melantai" (performing everyday activities while sitting on the floor). Various layers of activities are leveled to provide a maximum available surface. With arrangement through leveling, there will be extra spaces between surfaces that can be repurposed as storages. Another issue was that the overlapping activities have caused objects to be stacked and pushed to the corner. Without proper storing units, the occupants must dig around items that will further clutter the available space. Therefore, with additional storage that can be found either underneath, above, or beside the available surface, it will be more open for the occupants' daily activities. Figure 6 shows how DI visualizes the concept.

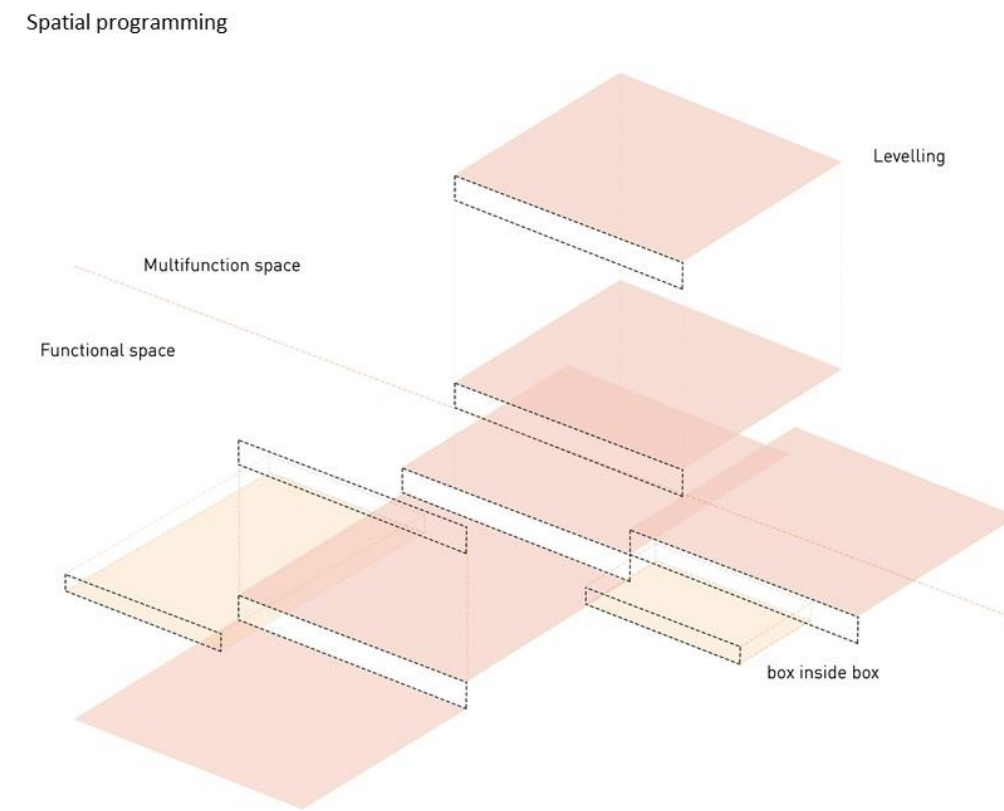

Multiple Layer by Levelling \& Nesting
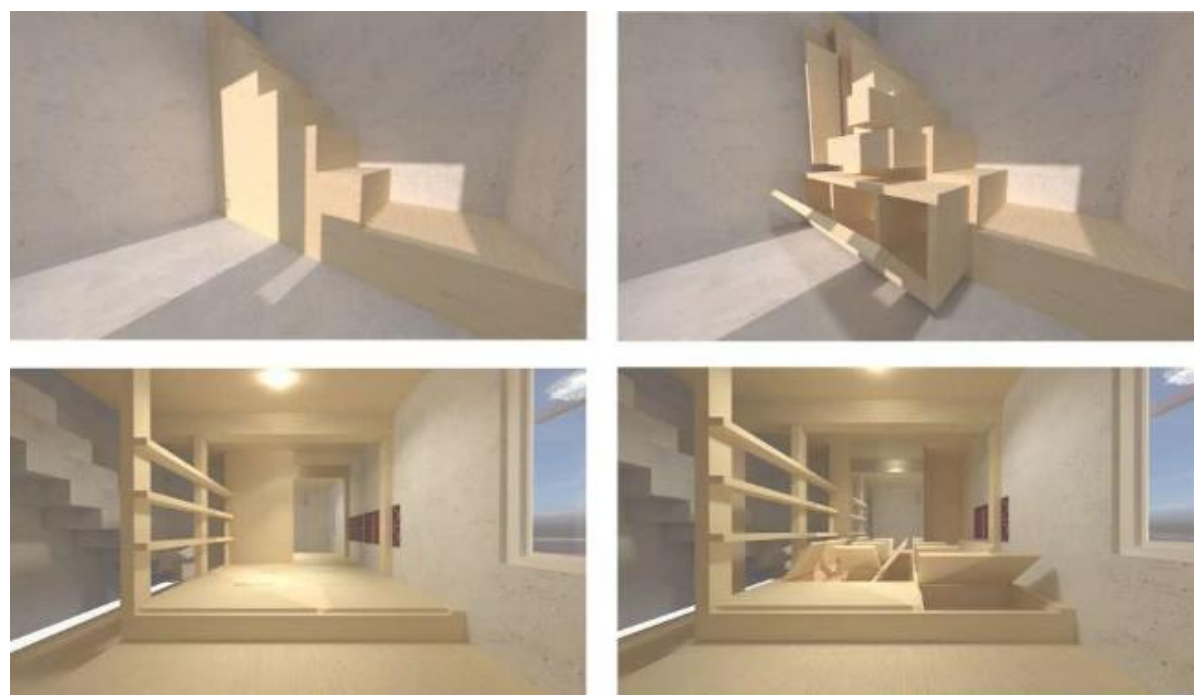

Figure 6. Concept and design proposal for the unit at Kampung Lodan 
The coupling unit in Kampung Tongkol was quite problematic in terms of the social relationship between the occupants. Tensions among the residents had split the unit into two separate entrances. According to NA's (the architect for the coupling unit 02) conversation with the residents, the spatial debate occurred after the house was cut in 2015. With less space, the occupants were forced to share their kitchen and semi-public areas. It was in the kitchen that the tension mostly arose, since R's uncle held most of his activities there.

The dilemma between two households prompted a new idea for NA to separate each household's sharing area. NA took stacking as her spatial programming idea with a maximum opening. Increasing more open areas in the house was intended to improve air quality. The current house was humid and dark due to its single opening at the back. By increasing the house's access to fresh air and natural light at the front and back, and separating the shared area of the two households, NA wished to reduce negative interaction between families and thus proposed a new design, as seen in Figure 7.

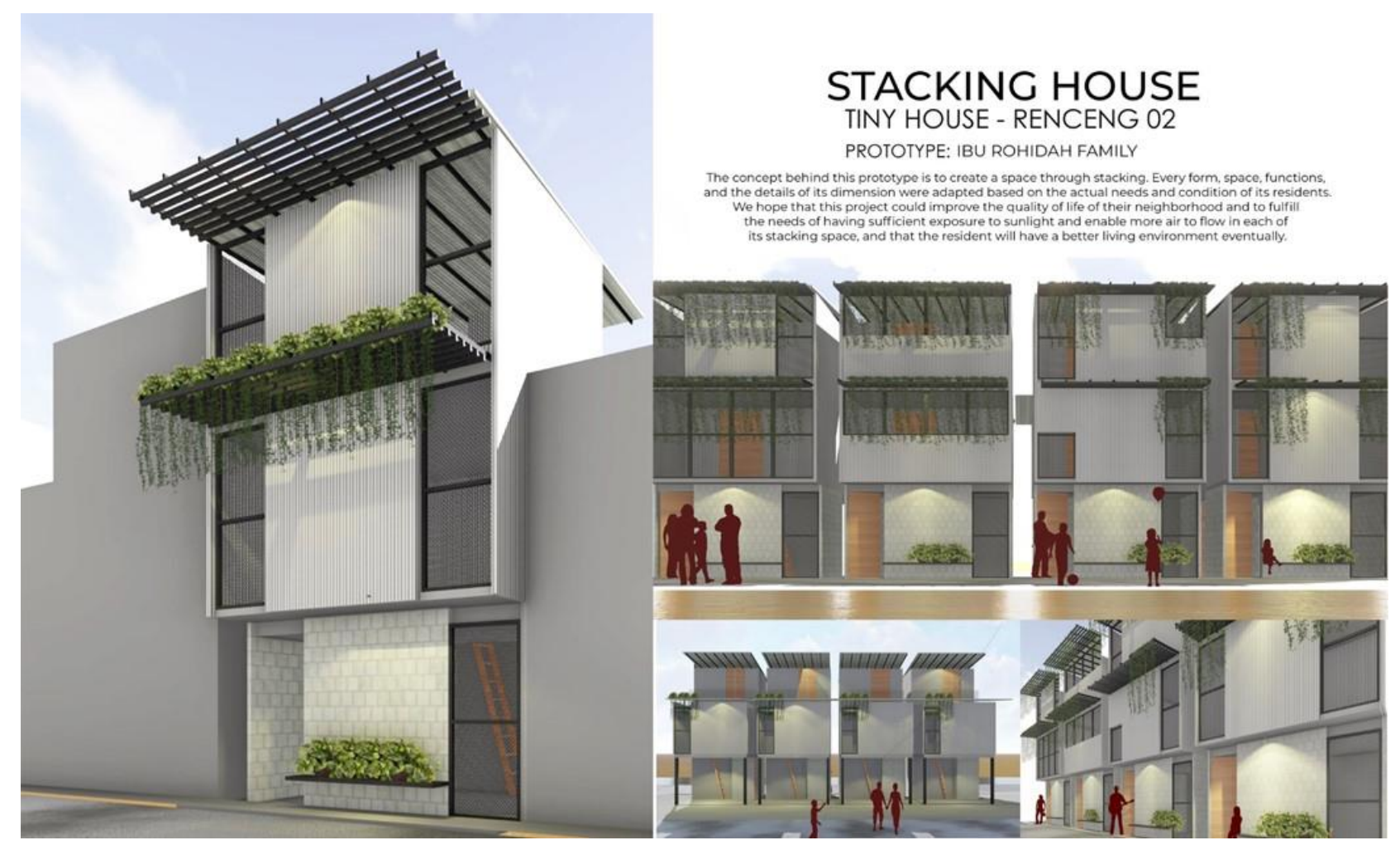

Figure 7. Design proposed for the unit at Kampung Tongkol

N (the architect for Coupling Unit 03) and RFA (architect for Coupling Unit 04) had similar approaches to the residents at Kampung Krapu. Both architects were concerned about poor air quality in the rear rooms with no access to fresh air. Besides the availability of proper ventilation, 
both $\mathrm{N}$ and RFA were also focusing on providing more space for further self-development and financial empowerment, ideas that had been presented to them by the residents in their desire for more available rental space.

In Coupling Unit 03, $\mathrm{N}$ focused on the health issue by proposing a vertical open space. Vertical ventilation would reduce humidity levels concentrated in the wet area. As the ventilation extended to the rooftop, the design would allow constant air circulation throughout the house. With vertical ventilation, $\mathrm{N}$ reduced health risk and opened a spacious area to inhabit. $\mathrm{N}$ also proposed a flexible and foldable stairwell that created more open space, as shown in Figure 8.

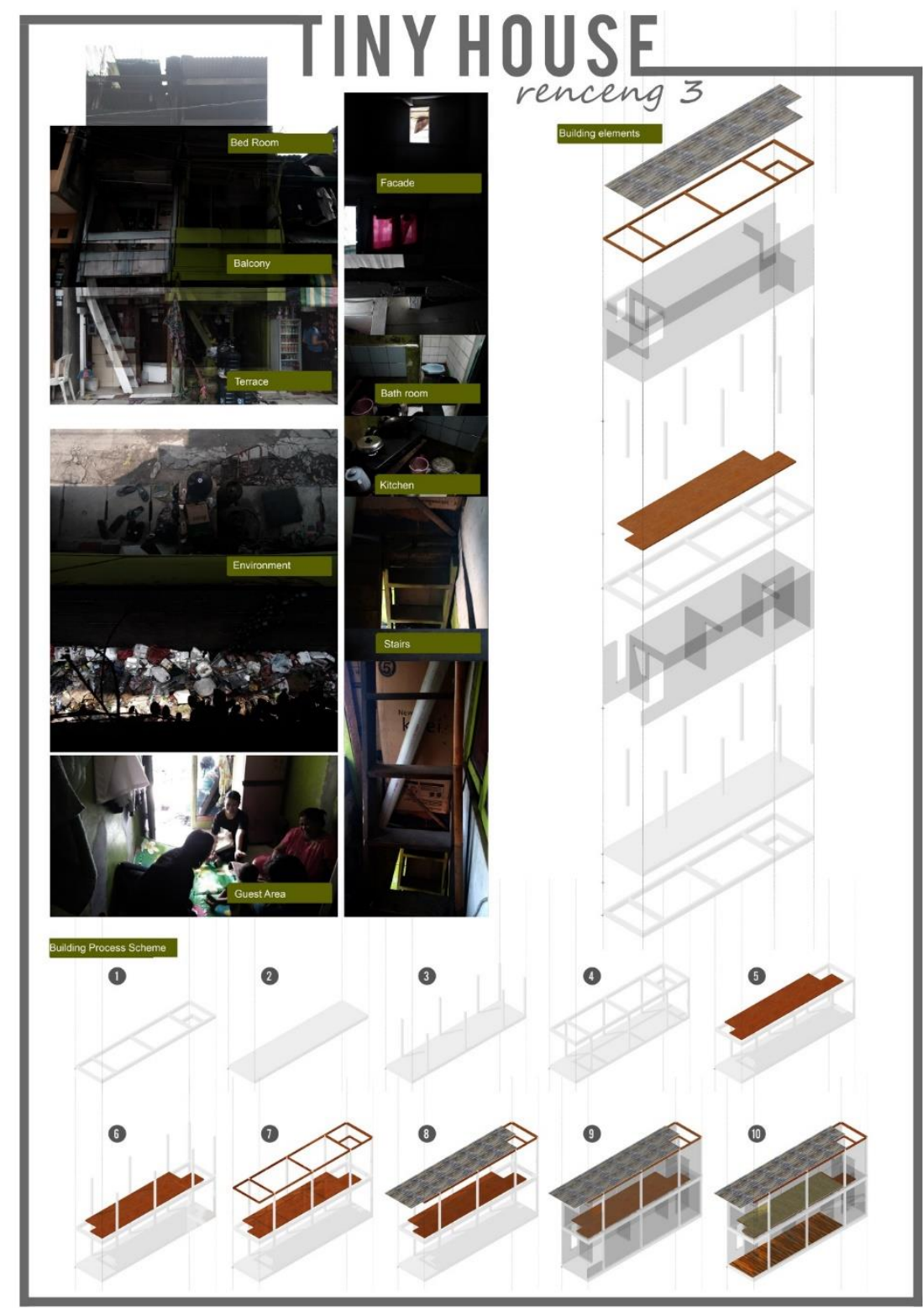

Figure 8. The concept and design proposed for the Kampung Krapu unit 03 
Coupling Unit 04 has an uneven number of residents in each house. $\mathrm{J}$ and his 21 family members live in a unit that is $10 \mathrm{~m}^{2}$ smaller than E's house (J's house is $\sim 18 \mathrm{~m}^{2}$, while E's is $\sim 28 \mathrm{~m}^{2}$ ). Both have three floors. Providing healthy air circulation and reducing humidity levels is important for RFA and his team. Based on RFA's interview with $\mathrm{J}$ and $\mathrm{E}$, flexible space is crucial to supporting the daily lives of the occupants. Especially with each place sheltering more than one household, privacy becomes a luxury for the residents in both houses. RFA designed moveable and foldable partitions to provide personal space. These foldable panels also serve as an alternative mode of increasing air circulation inside the house. With his team, RFA presented their concept in Figure 9.

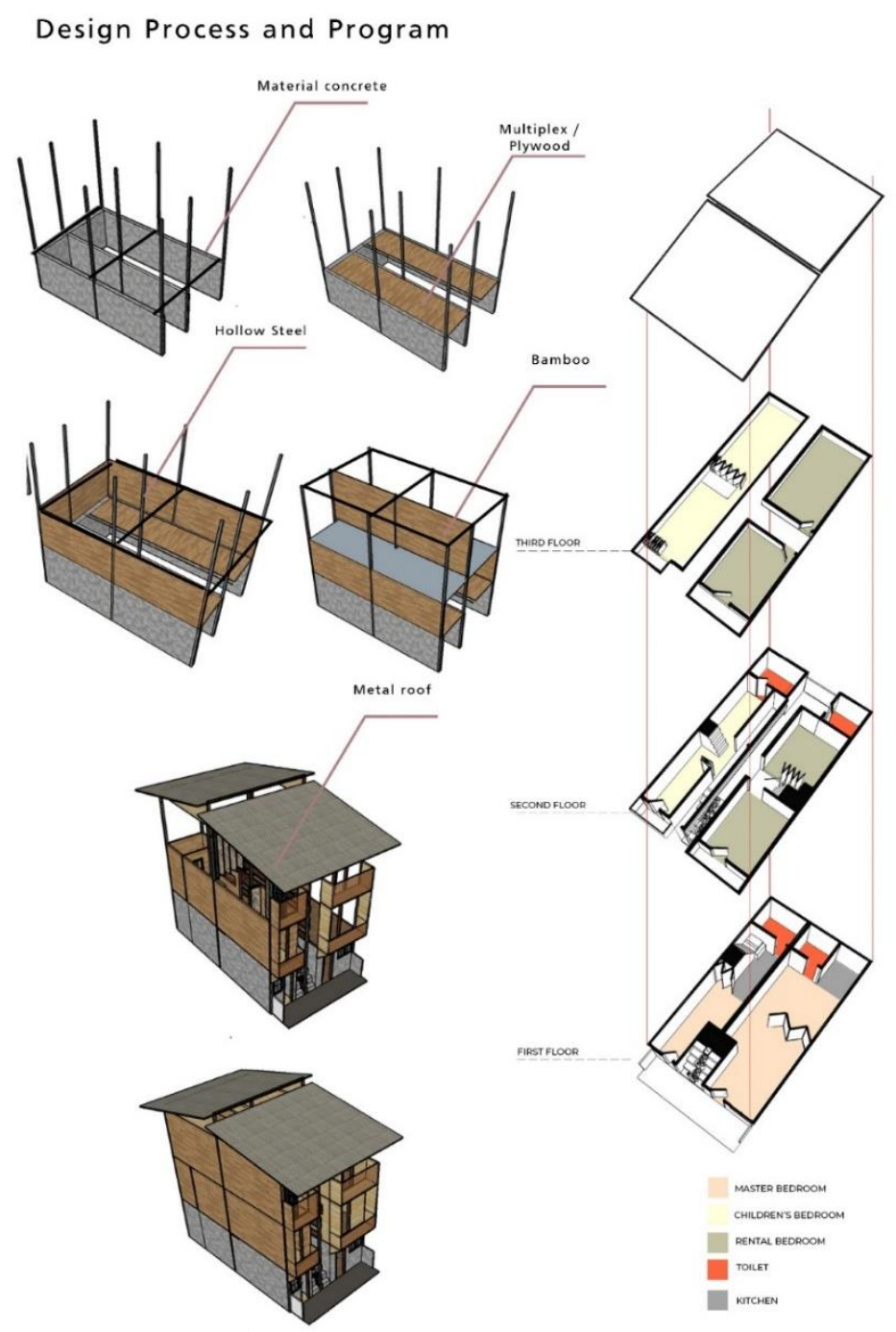

Figure 9. The concept and design proposed for the Kampung Krapu unit 04

\subsection{Implementing PAR as tools of inquiry}

In the KAKC housing redevelopment project, each architect offered their approach to the on-site issues. PAR was introduced as a tool of inquiry to produce a domestic space fit for the occupants' daily needs and possible development in the future. With PAR, stakeholders imagined their space in 
the current setting and projected it into the future. To design their houses, DI and NA focused on their activities while RFA and $\mathrm{N}$ were more concerned with building construction and feasibility to create more space in the future. Both approaches complied with the guidelines given, which were to design healthy, affordable homes based on the existing sites, daily activities, occupants' needs, available budgets, and future improvements. However, most importantly, all the architects had taken PAR to enhance their creative approach to dwellings in KAKC.

As a tool for inquiry, PAR was interpreted and implemented with different results by each architect. NA tackled the issue of sociospatial conflict between residents. Both DI and NA used PAR to observe the occupants' daily activities and, from that, domestic space production. From the participation perspective, DI's and NA's designs allowed the users to gain control of their living space. Both architects adopted PAR as their tool to understand the spatial practices in each household, then incorporated those dwelling habits into their design-DI through the "melantai" idea and NA highlighting the separation. On the other hand, N and RFA took PAR as their tool to investigate occupant room requirements rather than their daily activities and habits. The spatial needs are literally translated from their initial idea. By focusing on the health and structural aspects, $\mathrm{N}$ and RFA designed a domestic space that allowed flexibility and adaptability to future changes.

At first glance, the design proposal made by DI and NA did not meet Criteria \#4 in TOR, where the proposed idea could be developed into a core house plan for kampungs in Jakarta. The design was based on the inhabitants' daily activities, resulting in a specific set of spaces to support their everyday lives. The approach was intimate and explicitly hewed to streams of dwelling habits. The designs proposed by $\mathrm{N}$ and RFA also showed potential as prototypes for kampung settlements in Jakarta. The design promotes flexible spatial use, with sensitivity to technical and buildability issues.

A dwelling is a cultural artifact (Coolen \& Meester, 2012), a notion that could not be more accurate in the context of KAKC. Dwelling, although it is a product of self-implication, can also be projected to the outside, to the community. The house redevelopment in KAKC is the epitome of how domestic space-making contributes to the neighborhood commons. For the homeowners, the designs resonated with their daily needs, and it seems impossible to be replicated for others. However, the designs offered a new perspective-a fresh approach-for self-renovation projects in kampungs. DI's idea of various storage systems can be replicated to houses less than $18 \mathrm{~m}^{2}$ in size. The design proposal made by NA can be simplified and implemented for other settlements with double entrances or units with more than one household. N's and RFA's designs can be applied to houses with poor air ventilation and high humidity-a common threat found in most kampung 
residences near rivers and flexible spaces. The improvement in KAKC reflects the cyclical phenomenon mentioned by Hamiduddin (2017). The cutting in 2015 was a community-driven change in shaping people's spaces". Now it is the other way around.

\section{Conclusion}

Based on the housing redevelopment project in $\mathrm{KAKC}$, there are two conclusive remarks. First, PAR as a tool of inquiry, must not be perceived as a rigid method with output-based goals. Instead, PAR emphasizes the pedagogical experience and how knowledge value is shared between all stakeholders in most of its process (Kindon et al., 2007b; McTaggart, 2006). From the project, we found two outcomes based on PAR: the way participatory is used to see the everyday spatial practice and to detect flaws in constructions. However, the project must be followed to the construction level, showing that PAR is a continuous commitment made by all stakeholders. When the houses are built and activities resume in the new space, it will be the right time to see whether PAR works or fails.

The second conclusive remark follows the first one, where PAR requires all stakeholders to participate from the beginning to the end. Participating from the early step will increase responsibility to the project. Unfortunately, professionals, the community, and homeowners are all participating in various different levels for the house redevelopment project in KAKC. Therefore, in achieving a successful PAR and collectively accepted output, all stakeholders' contributions must be taken into account from the beginning until the end.

\section{Acknowledgement}

Our deepest gratitude to KAKC community for their support and enthusiasm in this project, both as participants as well as mediators for our discussion. Thank you to Inten Gumilang who helped us collecting and recording data, following up to architects on their schedule, and managed meetings flawlessly. Thank you to the architects, DI, NA, N as well as RFA and his team (RN, NRL, and NHN). Finally, thank you to the Directorate of Research and Community Engagement Universitas Indonesia for their financial support under the community engagement grants number NKB1390/UN2.R3.1/HKP.05.00/2019.

\section{Author Contribution}

The paper began with a brainstorming session between Herlily, Amira Paramitha, and Elita Nuraeny. The discussion began with a wrap-up of the community engagement project and then 
further analyzed its success and failures. The idea then further developed into structure by Paramitha and Nuraeny, while supervised by Herlily. The idea was further developed and written by Nuraeny in a research manuscript while Paramitha provided with additional information and data, such as images as well as interviews with locals. All authors discussed the results and contributed to the final manuscript.

\section{References}

Awan, N., Schneider, T., \& Till, J. (2011). Spatial Agency: Other Ways of Doing Architecture. London \& New York: Routledge.

Badan Pusat Statistik Provinsi DKI Jakarta (2019). Provinsi DKI Jakarta dalam Angka. Jakarta: CV Nario Sari.

https://jakarta.bps.go.id/publication/2019/08/16/eea4f4b387c3024bb4a3a7fc/provinsi-dkijakarta-dalam-angka-2019.html

Benson, M. \& Hamiduddin, I. (2017). Self-build Homes: Social Values and the Lived Experience of Housing in Practice in M. Benson \& I. Hamiduddin (Eds.). Self-Build Homes: Social Discourse, Experience and Directions (pp. 1-14). London: UCL Press. https://library.oapen.org/bitstream/handle/20.500.12657/31078/639594.pdf?sequence=1\#page $=19$

Caan, S. (2011). Rethinking Design and Interiors: Human Beings in the Built Environment. London: Laurence King Publishing Ltd. http://repository.fue.edu.eg/xmlui/bitstream/handle/123456789/4366/7191.pdf?sequence=1

Cobban, J.L. (1993). Government Housing Policy in Indonesia 1900-1940. GeoJournal, 29(2), 143-154. https://doi.org/10.1007/BF00812811

Colombijn, F. (2010). Under Construction: The Politics of Urban Space and Housing during the Decolonization of Indonesia, 1930-1960. Leiden: KITLV Press. https://biblio.ugent.be/publication/3158759/file/3158763

Coolen, H. \& Meesters, J. (2012). Editorial Special Issues: House, Home and Dwelling. Journal of Housing and the Built Environment, 27, 1-10. https://doi.org/10.1007/s10901-011-9247-4

De Carlo, G. (2005). Architecture's Public in P.B. Jones, D. Petrescu, \& J. Till (Eds.), Architecture and Participation (pp. 3-19). London \& New York: Spon Press.

Dovey, K. \& Dickson, S. (2002). Architecture and Freedom? Programmatic Innovation in the Work of Koolhaas/OMA. Journal of Architectural Education, 5-13.

https://doi.org/10.1162/104648802321019128 
Ford, J. \& Gomez-Lanier, L. (2017). Are Tiny Homes Here to Stay? A Review of Literature on the Tiny House Movement. Family and Consumer Sciences Research Journal, 45(4), 394-405. https://doi.org/10.1111/fcsr.12205

Hairani, L. (June 23, 2017). Gugun Muhammad: Agen Perubahan Kampung Pinggir Ciliwung. Tетро. https://metro.tempo.co/read/887015/gugun-muhammad-agen-perubahan-kampungpinggir-ciliwung/full\&view $=\mathrm{ok}$

Hamdi, N. (2010). The Placemaker's Guide to Building Community. London: Earthscan Ltd.

Hamiduddin, I. (2017). Community Building: Self-build and the Neighbourhood Commons in M. Benson \& I. Hamiduddin (Eds.) Self-Build Homes: Social Discourse, Experience and Directions (pp. 17-37). London: UCL Press.

https://library.oapen.org/bitstream/handle/20.500.12657/31078/639594.pdf?sequence=1\#page $=19$

Harjoko, T.Y. (2009). Urban Kampung: Its Genesis and Transformation into Metropolis, with Particular Reference to Penggilingan in Jakarta. Germany: VDM Publishing. https://catalogue.nla.gov.au/Record/4665099

Heidegger, M. (2001). Poetry, Language, Thought. New York: Harperperennial. http://townsendgroups.berkeley.edu/sites/default/files/heidegger_the_thing.pdf

Jones, P.B., Petrescu, D., \& Till, J. (2005). Introduction in P.B. Jones, D. Petrescu, \& J. Till (Eds.) Architecture and Participation (pp. xii-xv). London \& New York: Spon Press. https://www.routledge.com/Architecture-and-Participation/Jones-PetrescuTill/p/book/9780415317467

Katoppo, M.L. \& Sudradjat, I. (2015). Combining Participatory Action Research (PAR) and Design Thinking (DT) as an Alternative Research Method in Architecture. Procedia - Social and Behavioral Sciences, 184, 118-125. https://doi.org/10.1016/j.sbspro.2015.05.069

Kilman, C. (2016). Small House, Big Impact: The Effect of Tiny Houses on Community and Environment. Undergraduate Journal of Humanistic Studies, 2, 1-12. https://www.semanticscholar.org/paper/Small-House\%2C-Big-Impact\%3A-The-Effect-ofTiny-Houses-Kilman/27328c4ba21b4f6ae467210ddffd3edb2da8fa4b

Kindon, S., Pain, R., \& Kesby, M. (2007a). Introduction: Connecting People, Participation and Place in S. Kindon, R. Pain, \& M. Kesby (Eds.). Research Approaches and Methods: Connecting People, Participation and Place (pp. 1-5). New York: Routledge. https://www.acme-journal.org/index.php/acme/article/download/779/638 
Kindon, S., Pain, R., \& Kesby, M. (2007b). Participatory Action Research: origins, approaches and methods in S. Kindon, R. Pain, \& M. Kesby (Eds.). Research Approaches and Methods: Connecting People, Participation and Place (pp. 9-19). New York: Routledge.

Kusno, A. (2012). Housing the Margin: Perumahan Rakyat and the Future Urban Form of Jakarta. Indonesia, 94, 23-56. https://doi.org/10.5728/indonesia.94.0023

Lefebvre, H. (1991). The Production of Space (D. Nicholson-Smith, Trans.). Oxford, UK \& Cambridge, USA: Basil Blackwell, Inc. (Original work published 1974, 1984). https://www.wiley.com/en-gb/The+Production+of+Space-p-9780631181774

McTaggart, R. (1994). Participatory Action Research: Issues in Theory and Practice. Educational Action Research, 2(3), 313-337. https://doi.org/10.1080/0965079940020302

Martin, D.G. (2003). Enacting Neighborhood. Urban Geography, 24(5), 361-385. https://doi.org/10.2747/0272-3638.24.5.361

Nurgandarum, D., Inavonna, \& Ischak, M. (2019). Understanding Unplanned Settlement Structure as a Result of Self-organization in Jakarta. International Journal of Scientific \& Technology Research, 8(11), 2459-2465. http://libprint.trisakti.ac.id/1343/

Roth, S. (1999). The State of Design Research. Design Issues, 15(2), 18-26. https://doi.org/10.2307/1511839

Shearer, H., \& Burton, P. (2018). Towards a Typology of Tiny House. Housing, Theory, and Society, 1-20. https://doi.org/10.1080/14036096.2018.1487879

Simon, H. A. (1972). The Sciences of the Artificial (3rd ed.). Massachusetts: MIT Press.

Sloterdijk, P. (2016). Foams: Spheres III. California: Semiotext(e). https://mitpress.mit.edu/books/foams

Stickells, L. (2011). The Right to the City: Rethinking Architecture's Social Significance. Architectural Theory Review, 16(3), 213-227. https://doi.org/10.1080/13264826.2011.628633

Suryo, M.S. (2017). Analisis Kebutuhan Luas Minimal pada Rumah Sederhana Tapak di Indonesia. Jurnal Permukiman, 12(2), 116-123. http://dx.doi.org/10.31815/jp.2017.12.116\%20-\%20123

Taylor, J.L. (1987). Evaluation of the Jakarta Kampung Improvement Program in R.J. Skinner, J.L. Taylor, E.A. Wegelin, \& UN Centre for Human Settlements (HABITAT) (Authors) Shelter Upgrading for the Urban Poor: Evaluation of Third World Experience. Manila: Island Publishing House, in Co-operation with the United Nations Centre for Human Settlements (HABITAT) and the Institute for Housing Studies (BIE).

https://www.cochranelibrary.com/cdsr/doi/10.1002/14651858.CD010067.pub2/references 
Till, J. (2005). The Negotiation of Hope in S. Kindon, R. Pain, \& M. Kesby (Eds.) Research Approaches and Methods: Connecting People, Participation and Place (pp. 19-41). New York:

Routledge.

http://www.mom.arq.ufmg.br/mom/biblioteca_novo_2/arquivos/till_negotiation.pdf

Till, J. \& Schneider, T. (2005). Flexible Housing: The Means to the End. Architectural Research Quarterly, 9(3-4), 287-296. https://doi.org/10.1017/S1359135505000345

Widyahantari, R., Alfata, M.N.F., Hermawan, Y. (2013). Simulasi Ruang Gerak dalam Hunian Sederhana Berdasarkan Antropometri Manusia Indonesia: Menuju Standarisasi Perencanaan dan Perancangan Hunian Sederhana yang Ergonomis. Jurnal Standarisasi, 15(1), 36-46. https://js.bsn.go.id/index.php/standardisasi/article/view/657

Yudhohusodo, S. \& Salam, S. (1991). Rumah untuk Seluruh Rakyat (Eds.). Jakarta: INKOPPOL, Unit Percetakan Bharakerta.

http://www.worldcat.org/title/rumah-untuk-seluruh-rakyat/oclc/555243381 